\title{
DIASPORA FAMILY VIEWS ON LEARNING LATVIAN IN DISTANCE LEARNING CLASSES BY THE LATVIAN LANGUAGE AGENCY
}

\author{
Linda Krastiṇa \\ Daugavpils University, Latvia \\ Sandra Zariṇa \\ Daugavpils University, Latvia
}

\begin{abstract}
Latvian live outside Latvia in many countries of the world. With the concern for the preservation of Latvian it is disturbing that less than a half of Latvian diaspora families speak Latvian at home, therefore children have a weak proficiency of Latvian or lack it altogether. What is positive about the present situation is that almost all Latvians living in foreign countries wish their children to learn Latvian and choose distance learning classes for language acquisition and improvement, including those provided by the Latvian Language Agency (henceforth - LLA). The aim of the present research is clarifying the motivation of diaspora families to choose for their children distance learning classes of Latvian provided by the LLA and investigating the views of the families on the role of distance classes in the process of learning Latvian. For research data collection, a digital survey questionnaire was compiled and e-mailed to all families participating in distance classes of learning Latvian organized by the LLA in different countries of the world. The research reveals that the majority of the surveyed family children do not attend weekend Latvian schools and prefer regular, systemic language learning classes under the guidance of professional teachers from Latvia. The families admit that distance classes are a convenient mode of language learning, yet the greatest challenges in teaching and sustaining Latvian outside Latvia are the lack of the Latvian linguistic environment and lack of time for engaging with the child, whereas those in distance learning are children's busyness and lack of motivation for language learning.
\end{abstract}

Keywords: diaspora, Latvian language learning, distance learning classes.

\section{Introduction and Literature Review}

The relevance of the topic is determined by the aim of the document “Latvia’s Sustainable Development Strategy until 2030”, which highlights the need to preserve and develop Latvia's cultural capital and promote a sense of belonging to the Latvian cultural space by developing a competitive national identity based on public creativity. The strategy states that in the context of global and European cultural diversity, it is important for Latvia to preserve and develop its identity, language, national cultural values, and way of life. Modern national 
identity, which can be interpreted in a broader sense, includes all Latvians who feel belonging to the Latvian cultural space (Latvija 2030, 2010).

According to the data of 2011, the number of native speakers of Latvian reaches 1.55 million, and only 1.16 million of them live in Latvia, the rest live in various countries of the world (Vanags, 2020). The study "State Language Situation in Latvia: 2016 - 2020" indicates that while living abroad, the use of Latvian among Latvians decreases and functionally narrows. Before leaving Latvia, Latvian emigrants had weaker English and other home country's language skills, but while living in exile, their skills of different languages gradually improve, but at the same time Latvian skills deteriorate in all age groups. The data obtained in this study show that $41 \%$ of children have poor or no Latvian skills, and only $46 \%$ of families living outside Latvia speak Latvian as a spoken language at home (LVA, 2016). At the same time, almost all Latvian parents living abroad want their child to speak Latvian, and $6-7 \%$ of diaspora parents choose distance learning classes for their children to learn and improve their Latvian (LVA, 2020). This study also reveals that Latvian children whose families use distance learning have significantly better Latvian skills than those who do not use distance learning opportunities (Ministry of Education and Science, 2020).

In 2016, the Latvian Language Agency (hereinafter - LLA), which is responsible for promoting Latvian learning worldwide, accepted the challenge to provide children and young people anywhere in the world with the opportunity to learn and improve Latvian. In addition, not only to provide an opportunity to learn and practice independently, but to do it more purposefully - together with the teacher, using a wide base of learning resources and tasks (Kazāka \& Gribusts, 2018). Since then, LLA has been offering distance learning classes for learning Latvian in distance learning for 7-15-year-old diaspora children, using online classes as the main form of study. The aim of the paper is to analyse the motivation of the families of distance learning students to choose Latvian distance learning classes offered to their child by LLA and to evaluate the importance of the offered distance learning classes in the Latvian acquisition process.

An online questionnaire was used in the study to collect qualitative and quantitative data. The electronic questionnaire was sent to the families of 200 LLA distance learning students learning Latvian in the diaspora in 36 countries around the world.

The study identified the biggest challenges for families of distance learning students in teaching and maintaining Latvian outside Latvia, the ways in which each family promotes language maintenance, why they choose distance learning classes, which are motivating and disruptive conditions for a child learning Latvian in distance learning classes. 


\section{Methodology}

An online questionnaire was used to collect data in the study. The survey was conducted in December 2020 and January 2021.

The online questionnaire was chosen as the most appropriate form of the survey because the respondents are located in different countries of the world, and all respondents have access to the Internet and relevant technologies, as it is mandatory for LLA when parents apply for distance learning. The questionnaire included questions in which parents (1) expressed their opinion on whether they were satisfied with their children's Latvian skills and at what level they would like them to be; (2) indicated the types of language learning and the challenges in language learning; (3) substantiated the choice of distance learning classes organized by LLA; (4) evaluated and substantiated whether and why LLA classes have met their expectations, made recommendations for the improvement of these classes. The questionnaire included both closed, partially open, and open questions for obtaining qualitative and quantitative data. Thematic analysis was used to compile qualitative responses, assigning codes to the responses, grouping them accordingly, and finally quantifying them (Braun \& Clarke, 2006; Pipere, 2016).

The questionnaire was sent to the families of 200 LLA distance learning students studying Latvian in the diaspora in 36 countries around the world. Questionnaires were completed and submitted anonymously by 107 or $53.5 \%$ of respondents, representing 30 countries. Most respondents are from Great Britain, Ireland, the USA and Canada (Fig. 1) - from the countries where the largest Latvian communities live (Ministry of Foreign Affairs of the Republic of Latvia, 2015).

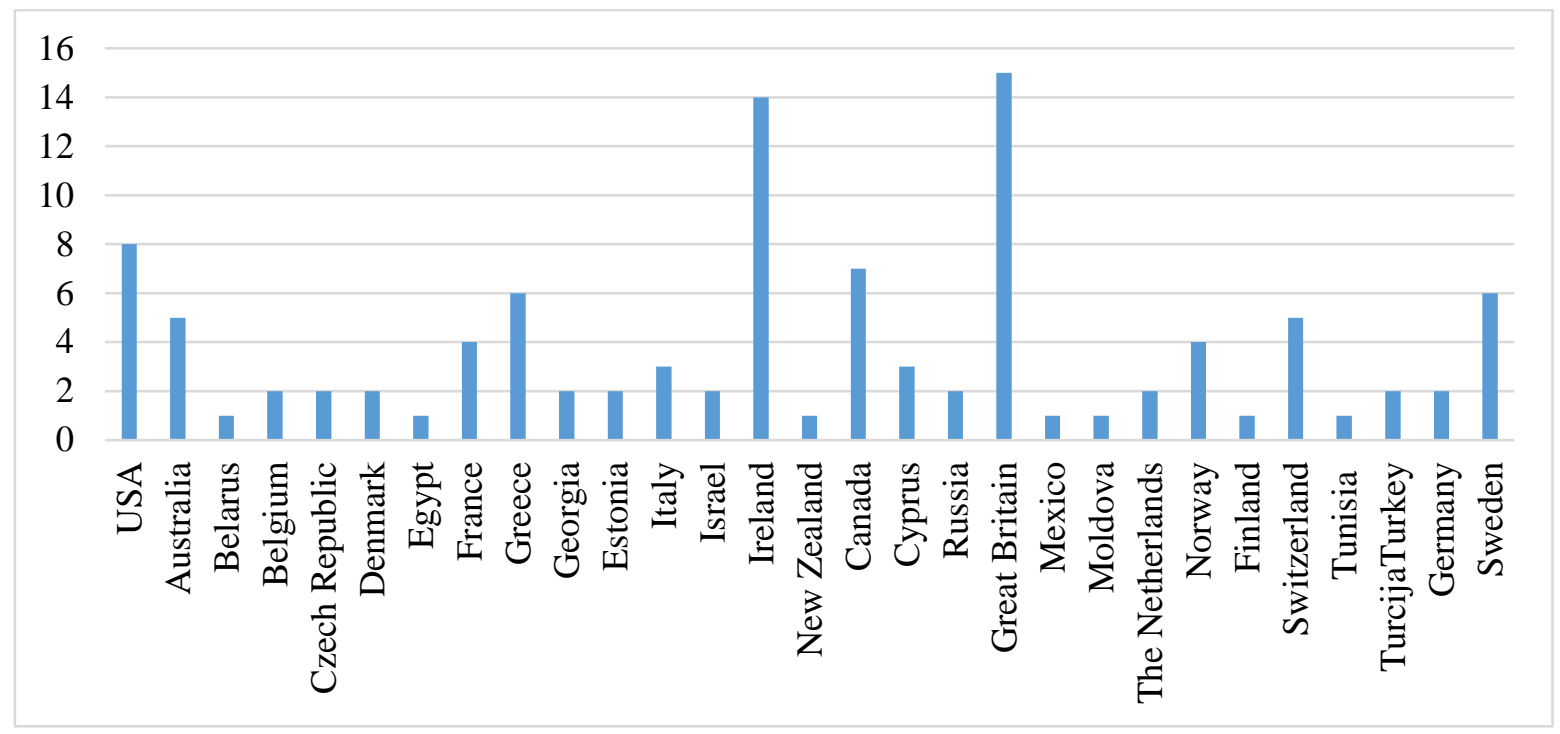

Figure 1 Countries Represented by the Respondents 
Respondents represent parents of children of different ages (7-15 years), mostly 8-11 years old (Fig. 2), which is in accordance with the age distribution in the groups of LLA distance learning classes.

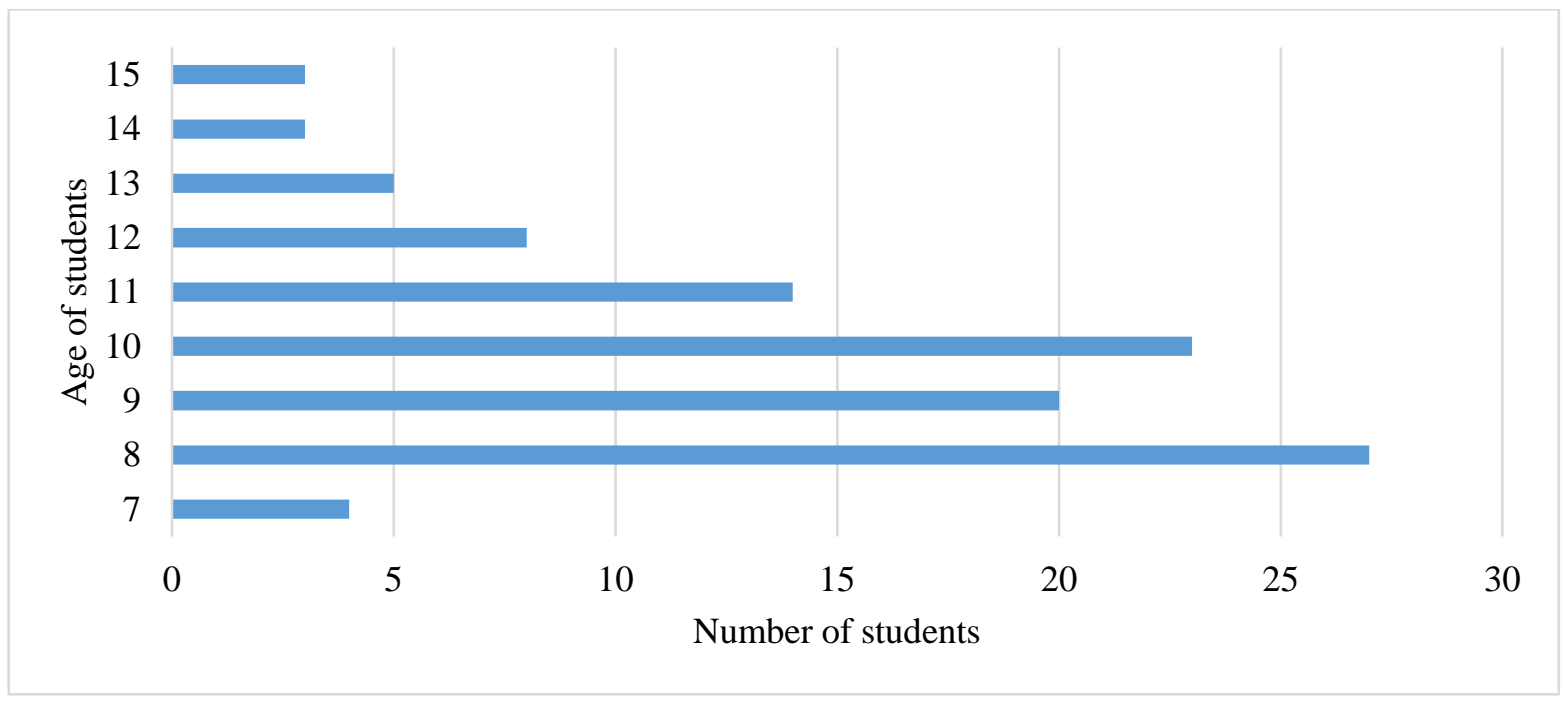

Figure 2 Age of Students

\section{Research Results}

The answers of the respondents confirm that the majority of the surveyed parents' children or $71 \%$ were born outside Latvia, but the remaining $29 \%$ - in Latvia. Most of the respondents are satisfied with their children's Latvian skills, but it is influenced by regular distance learning - in the first, second, third, or fourth year.

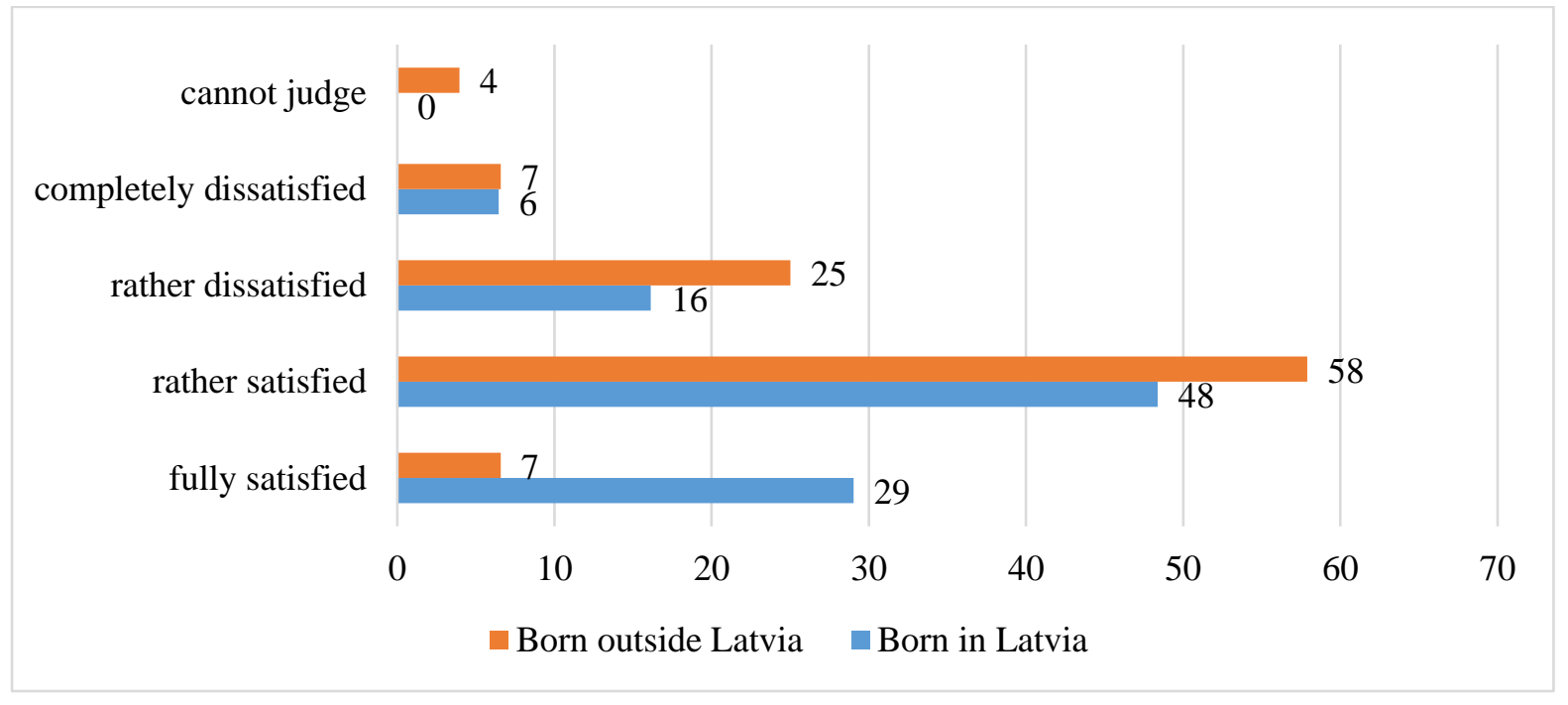

Figure 3 Parent's Satisfaction with Their Child's Language Skills (percentage) 
Parents' satisfaction with children's language skills differs for parents whose children were born outside Latvia and those whose children were born in Latvia (Fig. 3). The percentage of parents who are completely satisfied with their child's Latvian skills is greater among the one's whose child was born in Latvia, while the majority of parents of children born outside Latvia are dissatisfied with the child's Latvian skills.

Parents' satisfaction with their children's Latvian skills is in line with the data of the study "Language Situation in Latvia: 2016-2020" implemented within the state research program where (Ministry of Education and Science, 2020; LVA, 2020) Latvian children whose families use distance learning have significantly better Latvian skills than those who do not use distance learning opportunities.

Diaspora families apply their children for Latvian distance learning classes so that the children acquire, maintain, and improve their Latvian skills. Why is it important for parents living outside Latvia that the child understands Latvian? In the diaspora, the language of the host country is needed on a daily basis at school or work, in social communication, and the use of Latvian is gradually decreasing. As the most important respondents indicate the factor: language is necessary for communication with Latvian-speaking relatives and friends (84\%). Part of the diaspora regularly spend their holidays in Latvia, but relatives (often grandparents) and friends do not know the language of the respective home country, and, of course, prefer to speak their native language. Communication with relatives and friends is also done online through calls and video calls. The second most important factor - parents note that language is important for preserving Latvian identity (80\%). This is understandable, because the basis of national identity is formed by the Latvian language and cultural space, and they strengthen belonging to the nation and the state of Latvia (Latvija 2030, 2010). One of the respondents writes: Latvian culture is unique; if my daughter wants to look deeper into it, Latvian will be the bridge that will take her into this beautiful, inexhaustible and enriching world of the Latvian heritage. As the third most important factor, parents note the possibility that the child may one day return to Latvia, such an option is considered by $61 \%$ of respondents. $14 \%$ of respondents also indicate other reasons, such as, would like to speak Latvian with my child; it is important for me to speak to the child in the language I know best; it is possible that the child will one day study at a Latvian university; the more languages you know, the better; language is value.

It could be assumed that in the diaspora, where the home country's language is used on a daily basis, Latvian skills at conversational level could be sufficient, however, the questionnaire results show that $70 \%$ of respondents have high requirements - want a child to speak Latvian fluently, 29\% of respondents want their child to understand and be able to communicate in Latvian at the level of 
conversational language, only $1 \%$ of respondents do not care at what level language skills will be acquired.

Although all respondents have chosen distance learning classes for learning Latvian, there are other ways and opportunities to acquire, maintain and improve Latvian skills. Other options most often marked in the questionnaire are (Fig. 4): 1) read books, watch movies, play games / computer games, listen to music in Latvian (65\% of respondents), 2) family tries to spend as much time as possible in the Latvian environment, attend Latvian events in the host country, celebrate Latvian annual customs and public holidays at home (62 \% of respondents), 3) the child participates in camps in Latvia and/or goes to Latvia on holidays, meets Latvian-speaking relatives, friends (61\% of respondents).

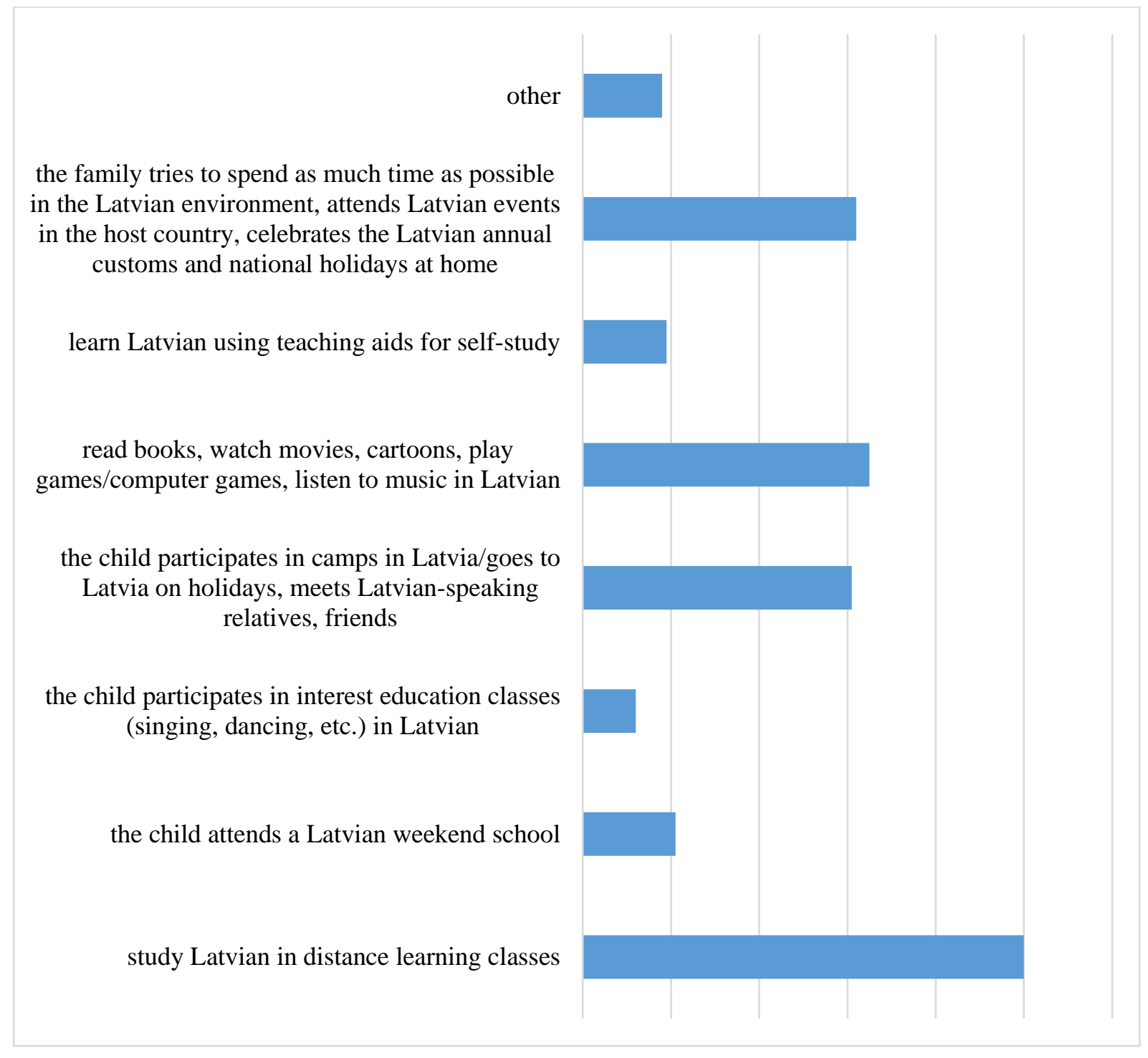

Figure 4 How Do Diaspora Children Learn and Maintain Latvian? 
Language learning requires a Latvian environment, so diaspora families try to attend classes and events in Latvian diaspora organizations. The study shows that only $21 \%$ of respondents' children attend Latvian weekend school. Some parents point out that there is no Latvian community nearby, others that there are no classes for children their age at the weekend school, still others - that getting to the weekend school takes a lot of time, but parents lack it.

$18 \%$ of parents indicate other ways, especially emphasizing that they speak Latvian or only Latvian with their children in the family, indicate that they watch Latvian TV programs, study not only in the classes offered by LLA, but also in distance learning at a Latvian comprehensive school.

Better results in language skills could be achieved by combining all or some of the above options, but many families do not have this possibility. The study reveals that children of 6 respondents learn Latvian only in distance learning classes, 1 child - only in distance learning classes and a mother tongue lesson in a Swedish school once a week, 1 child that only in distance learning and using self-study tools. These respondents account for $7.5 \%$ of all respondents.

In the questionnaire, respondents also note the biggest challenges in teaching and/or maintaining a child's Latvian skills outside Latvia. The easiest way to learn a language is in its natural environment, but the biggest challenge is the lack of a Latvian environment (72\%). Diaspora families look for the Latvian environment in Latvian weekend schools, but $29 \%$ of parents indicate that they do not have such opportunities. The Latvian environment would be available daily in the family, but $39 \%$ of respondents indicate that they lack time for activities with the child. Finally, the challenge is the child's lack of motivation to learn Latvian. This is indicated by $32 \%$ of respondents. It should be noted that the parents of these children themselves want the children to learn Latvian because they have enrolled their children on distance learning classes and this survey shows that their expectations about the level of language acquisition are quite high or high. It is difficult for a child to find and maintain this motivation on his/her own, because he/she lives in a different language environment in the home country and mostly uses the language of his/her home country. Other challenges mentioned by respondents include: child's busy schedule and heavy school load, fatigue, peculiarities of adolescence, lack of financial means to travel to Latvia or to purchase books, cultural content (films, theatrical performances, television programs, etc.) cannot be accessed online due to copyright restrictions.

Respondents provided many answers to the question why parents have chosen Latvian distance learning classes offered by LLA. These responses are categorized and quantified:

1) As all respondents have chosen Latvian distance learning classes, it must be concluded that their main wish is for the child to have the opportunity to learn Latvian. This was also confirmed by the answers 
to other questions. The results of the questionnaire reveal that $55 \%$ of respondents emphasize this goal, indicating that it is important to learn Latvian, for example, maintain and improve language skills, improve vocabulary, improve writing skills, improve grammar knowledge.

2) The study shows that $40 \%$ of respondents indicate expectations about the quality of classes under the guidance of a professional Latvian teacher. Parents emphasize that they want regular, high-quality training under the guidance of a professional Latvian teacher who speaks correct Latvian. This desire can be partly explained by the fact that in the diaspora Latvian schools the parents themselves work enthusiastically as teachers, and only some of them have pedagogical education, not all of these teachers have good Latvian skills, as well as most often integrated classes in Latvian and measures for the care of Latvian traditions take place, but less emphasis is placed on the systematic acquisition of the Latvian. Some parents mention that Latvians in the diaspora speak "with an ancient connotation", as well as that "the language of the home country dominates and the family no longer speaks good Latvian", but they would like to learn modern and correct Latvian. A professional educator would replace or supplement the parents' contribution when the children grow up, when the parents no longer have authority, and in a situation where the parents' language skills are insufficient.

3) $47 \%$ of all respondents indicate the need to study in a Latvian environment together with their peers. In distance learning classes, groups are made up of children of a similar age who live in different countries but are in a similar situation. This is an opportunity to be in the Latvian environment and see that Latvian is used not only in the child's family. Students have the opportunity to make Latvian-speaking friends. Respondents reveal that there is no diaspora organization nearby or there are no age-appropriate groups in the Latvian school, or the children in the Latvian school speak almost no Latvian.

4) $10 \%$ of respondents choose distance learning classes to create interest in the child in Latvian, create motivation to speak Latvian.

5) In turn, $8 \%$ of the surveyed parents highlight the encouragement of child's interests in Latvia, Latvian history, culture, Latvian, Latvian traditions as important. One of the respondents writes: Perhaps in a unique combination with other knowledge, at the same time knowing Latvian, a child can make a unique contribution to Latvia in his/her life.

6) $6 \%$ of the respondents show that parents consider re-emigration opportunities in the future, including studies in Latvian universities, which is the practical use of the language in the future. 
7) Other respondents' answers show that parents have chosen distance learning because they have heard positive feedback, because it is convenient to study online without leaving home and without spending a lot of time, because the classes are free and take place in small groups.

The majority of respondents (55\%) express the opinion that their expectations for the chosen form of study - distance learning - are fully met, there are no parents whose expectations were not met at all. Families value the highest (Fig. 5) convenience and accessibility (83\%) - they do not have to spend time and expenses on the road, and the professional work of teachers (82\%).

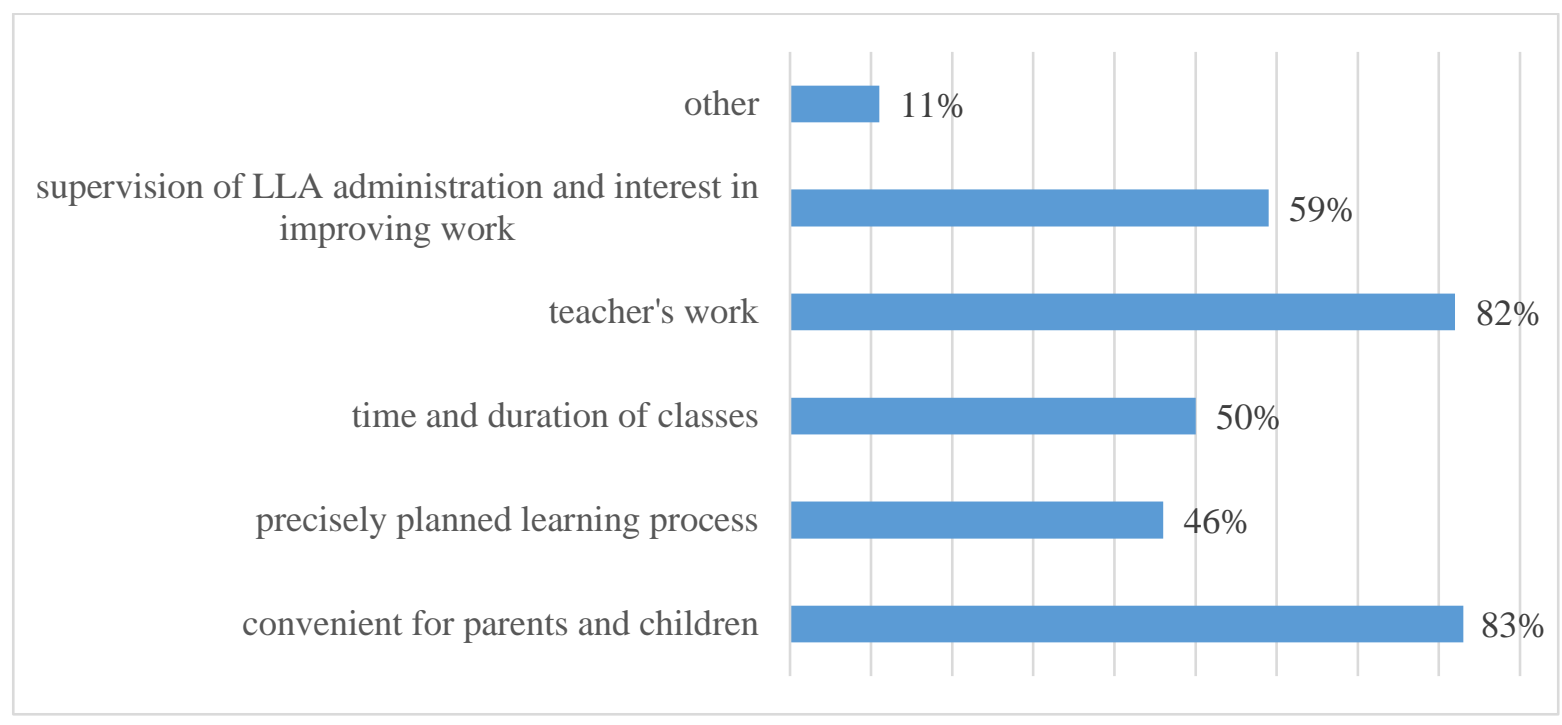

Figure 5 What Satisfies Parents in Distance Learning Classes the Most?

The supervision and interest of the LLA administration in improving the work (59\%), the appropriate time and duration of classes (50\%), as well as the precisely planned learning process (46\%) are also highly valued. Among other satisfactory conditions in the classes, the respondents mention teachers' enthusiasm, positive attitude, parents' meetings, recommendations, advice for parents, the involvement of parents in language learning, small groups, cooperation with the teacher, diversity in classes, classes are free, Latvian traditions and culture are acquired, special days are celebrated. What was said by one of the respondents reveals the fulfilled expectations: When I started training 4 years ago, I could not even realize how much the benefit would be.

When evaluating the disturbing conditions in distance learning classes, the respondents highlight (Fig. 6) the lack of motivation of the child (34\%) and the child's busyness at school and interest education, thus fatigue (27\%). 28\% of respondents point to problems with technology and internet speed, but when applying for classes, families were informed about the prerequisites for successful 
online classes. Other reasons are also mentioned, for example, that the class is boring, that the texts are too complicated, that they cannot fit into the rhythm of the online lesson, that there is too much free time in the online lesson. These observations point to the opportunities and the need to improve the quality of online lessons by improving teachers' competence. If a student is forced to work with learning content that does not correspond to his/her language skills, cognitive productivity decreases, self-esteem deteriorates, the student is unable to control his/her activities, worry about failure, emotional tension occurs, and it also reduces learning motivation and self-esteem (Anspoka, 2010).

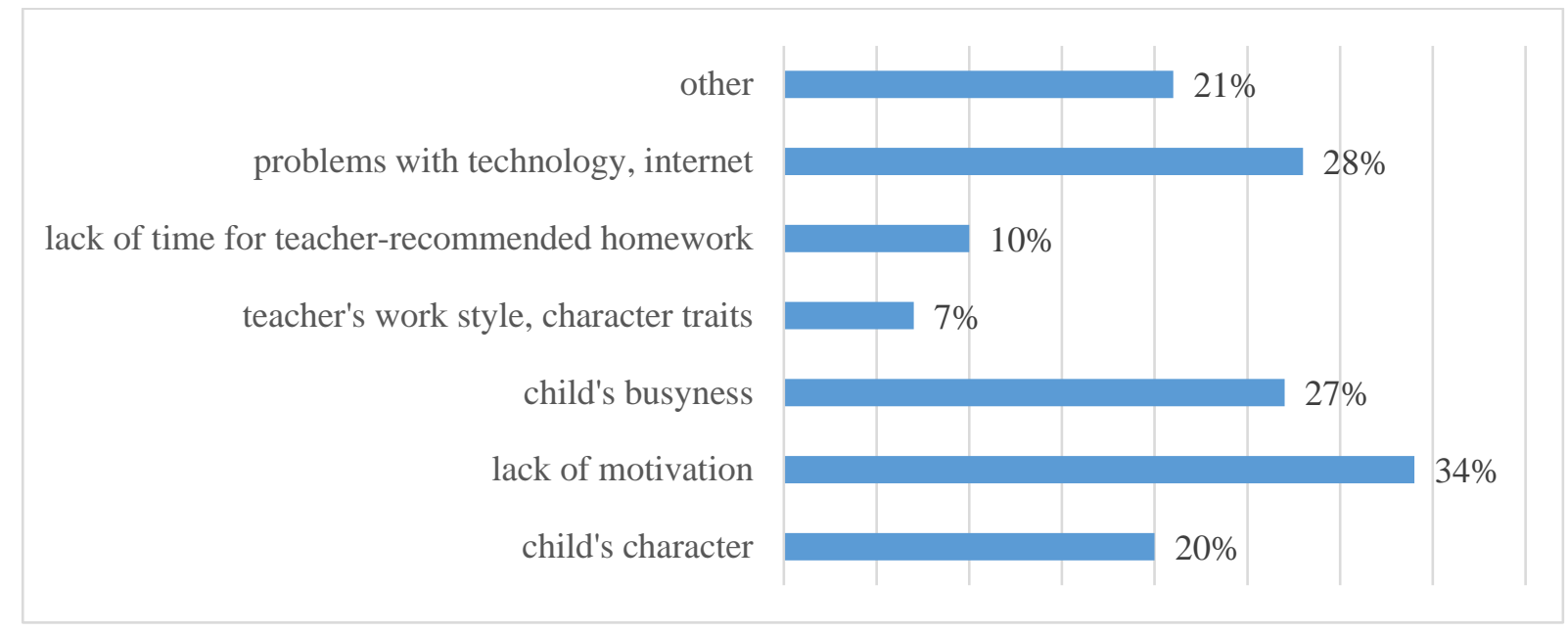

Figure 6 What Hinders a Child in Distance Learning Classes?

Respondents also provided recommendations for organizing distance learning classes. Among the recommendations are an enormous amount of thanks for this offer and the work of the teachers. These recommendations are categorized and quantified:

1) Most (9\%) respondents have expressed an opinion about homework. The recommendations are varied and contradictory: there are views on the need for them as well as against homework, as both children and parents are busy; there are opinions about what kind and on what topics homework they would like to have and where to place and summarize them.

2) $7 \%$ of respondents express an opinion on which language basic skills should be given more attention. One wants to spend more time talking, another wants to read, another wants to focus more on developing writing skills.

3) It is important for parents (7\%) to receive more frequent feedback on the child's progress, level of knowledge. Therefore, parents recommend 
more frequent online meetings, want to receive observations, suggestions and just talk about the language teaching experience.

4) Respondents (6\%) have expressed an opinion that indicates the need to differentiate work and facilitate the content - there are too complex texts, too complicated formulations of task and questions, children have different levels of knowledge and a different pace of work. Parents point out that if it is too difficult, motivation is lost.

5) Parents (4\%) want to get acquainted with the planned curriculum, the results to be achieved, follow it and get involved in the learning process outside of class.

6) Parents want (4\%) that teaching materials are available after class. This would allow parents to both keep track of what the child is learning and to get involved outside of the class. The digital platform used for distance learning has this possibility, so teachers should be encouraged to use it.

Among the recommendations are many different wishes, including the formation of new groups, so that more children in the diaspora have this opportunity to learn the language. Parents also want the opportunity for their children to meet in person - in camps that have been organized in the past, but currently such opportunities are not available due to Covid-19 restrictions.

\section{Conclusions and Discussion}

Research on the Latvian language situation confirms that Latvian skills of diaspora children have been deteriorating in recent years, especially for younger children and children born outside Latvia. At the same time, almost all Latvian parents living abroad want their child to speak Latvian, and 6-7\% of diaspora parents choose distance learning classes for their children to learn and improve their Latvian, and Latvian children whose families use distance learning have significantly better Latvian skills than those who do not use distance learning opportunities. Most parents of LLA distance learning students want their children to be fluent in Latvian.

Diaspora families use various ways and opportunities to maintain and improve children's Latvian skills, but for $7.5 \%$ of families, distance learning is almost the only option. This determines the need for greater availability of classes and pedagogical efficiency.

Children of the diaspora families are enrolled on distance learning classes in order to improve Latvian skills in planned, regular, high-quality classes in a convenient and modern way under the guidance of professional Latvian teachers together with Latvian-speaking peers. It is important for parents that their children develop a correct and modern Latvian. Diaspora families see distance learning 
classes as an opportunity to be in the Latvian environment and expand knowledge about Latvia, Latvian history, culture, Latvian traditions. The distance learning teacher is the one who ensures the connection with Latvia.

Diaspora families' expectations of distance learning have largely been met. Some families have applied for distance learning classes after positive feedback.

The study also reveals obstacles to language learning. The main ones are the child's lack of motivation to learn the Latvian, high workload at school and interest education, as well as too complicated learning content and insufficient differentiation of the study process during classes. Although in general parents are very satisfied with the quality of classes and the impact on the development of children's language skills, the parents' recommendations also point to the possibilities to improve the quality of classes and improve cooperation with parents.

The research raises topical questions for further research - what is the motivation of diaspora students to learn the Latvian from the student's point of view, how can it be improved and what are the specific pedagogical competencies of Latvian distance learning teacher for diaspora children to provide more effective and motivating classes.

\section{References}

Anspoka, Z. (2010). Valoda kā līdzeklis pamatizglītîbas programmā: dažas problēmas un risinājumi [ENG: Language as a tool in the basic education program: some problems and solutions]. ATTE Teacher of the 21st Century: Quality Education for Quality Teaching. Riga: LU, 25.-132.

Braun, V. \& Calrke, V. (2006). Using thematic analysis in psychology. Qualitative Research in Psychology, 3(2),77-101.

Kazāka, S. \& Gribusts, A. (2018). Floviňš - latviešu valodas tālmācība diasporas bērniem [ENG: Floviňš - distance learning of Latvian for diaspora children]. Journal "Tagad". Scientific methodological publication, 1/2018 (11), LVA. Retrieved from https://maciunmacies.valoda.lv/wpcontent/uploads/2019/10/TAGAD_1.2018_web_small.pdf

Latvija 2030. (2010). Latvijas ilgtspējīgas attīstības stratēgija lìdz 2030. gadam [ENG: Latvia's sustainable development strategy until 2030]. Retrieved from https://www.pkc.gov.lv/sites/default/files/inline-files/LIAS_2030_parluks_lv_0.pdf

LVA. (2016). Sociolingvistisks pētījums "Valodas situācija Latvijā: 2010-2015." [ENG: Sociolinguistic research "Language situation in Latvia: 2010-2015”] Scientific ed. L. Lauze, responsible ed. G. Maple. Retrieved from https://valoda.lv/wp-content/ uploads/docs/Petijumi/Sociolingvistika/VSL_2015_web.pdf

LVA. (2020). Study “Valodas situācija Latvijā: 2016-2020” [ENG: Language situation in Latvia: 2016-2020]. Research data from Gunta Klava's presentation at the LLA Latvian distance learning teachers' conference "lva.classflow.lv: experience, challenges and opportunities” on July 13, 2020. Retrieved from https://valoda.lv/petijumi/valodassituacija-latvija-2016-2020/. 
SOCIETY. INTEGRATION. EDUCATION

Proceedings of the International Scientific Conference. Volume V, May $28^{\text {th }}-29^{\text {th }}$, 2021. 560-572

Ministry of Education and Science. (2020). Valsts valodas politikas pamatnostādnes 2021.2027. gadam [ENG: State Language Policy Guidelines 2021-2027]. Draft guidelines. Retrieved from https:/www.izm.gov.lv/sites/izm/files/izmpamn_240820_vvpp1.pdf

Ministry of Foreign Affairs of the Republic of Latvia. (2015). Latvijas diaspora pasaule [ENG: Latvian diaspora in the world]. Retrieved from https://www.mfa.gov.lv/tautiesiemarzemes/latvijas-diaspora-pasaule

Pipere, A. (2016). Datu analīzes metodes kvalitatīvā pêtījumā [ENG: Data analysis methods in qualitative research]. From: K. Mārtinsone, A. Pipere, D.Kamerāde (ed.). Pētniecība: teorija un prakse [ENG: Research: theory and practice]. Rīga: RaKa. p.357.-411.

Vanags, P. (2020). Latviešu valoda. Nacionālā enciklopēdija. [ENG: Latvian Language. National Encyclopaedia]. Retrieved from https://enciklopedija.lv/skirklis/9891latvie\%C5\%A1u-valoda 